\section{Category}

Chemistry in

Medicine and

Biology

\section{Key words}

SARS-CoV-2

COVID-19

antimalarial

A. R. SURREY, H. F. HAMMER (STERLING-WINTHROP RESEARCH INSTITUTE,

RENSSELAER, USA)

The Preparation of 7-Chloro-4-(4-( $N$-ethyl- $N$ - $\beta$-hydroxyethylamino)-1-methylbutylamino)-quinoline and Related Compounds

J. Am. Chem. Soc. 1950, 72, 1814-1815.

\title{
Hydroxychloroquine - An Antimalarial to Fight COVID-19?
}<smiles>CC(=O)CCCCl</smiles>

$\underset{\mathrm{MeOH}}{\stackrel{\mathrm{NH}_{3} \text {, Raney-Ni, } \mathrm{H}_{2}}{\longrightarrow}}$ reductive amination<smiles>Clc1ccc2c(Cl)ccnc2c1</smiles><smiles>CCNCCO</smiles><smiles>CCN(CCO)CCCC(C)N</smiles><smiles>CCN(CCO)CCCC(C)N</smiles>
$S_{N} A r$

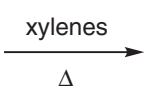<smiles>CCN(CCO)CCCC(C)=O</smiles><smiles>CCN(CC)CCCC(C)Nc1ccnc2cc(Cl)ccc12</smiles><smiles>CCN(CCO)CCCC(C)Nc1ccnc2cc(Cl)ccc12</smiles>

Significance: Hydroxychloroquine (HCQ) and chloroquine (CQ) have long been used as treatments for malaria and autoimmune diseases. Surrey and Hammer detailed the synthesis of HCQ, a potent antimalarial in 1950. In an effort to identify available drugs to fight SARS-CoV-2 it has been reported that CQ and HCQ in combination with azithromycin might have the potential to combat COVID-19.
Comment: HCQ is synthesized by reacting a diamine with 4,7-dichloroquinoline in an $\mathrm{S}_{\mathrm{N}} \mathrm{Ar}$ reaction. The diamine is synthesized by condensing 5chloro-2-pentanone with $\mathrm{N}$-ethylethanolamine, followed by reductive amination with ammonia. HCQ showed good antimalarial activity and recently has been found to inhibit SARS-CoV-2 infection in vitro (Cell Discovery 2020, 6, 16). 